Dialectologia 15 (2015), 117-135.

ISSN: 2013-2247

Received 13 March 2014.

Accepted 10 June 2014.

\title{
A SPEECH ACT ANALYSIS OF SELECTED YORÙBÁ ANTHROPONYMS
}

\author{
Rahim Kajogbola Ọmọlọsọ́ \\ Al-Hikmah University, Ilorin, Nigeria \\ gbolaloso2@yahoo.com
}

\begin{abstract}
This work employs a speech act approach to the analysis of Yorùbá indigenous names to emphasize that they are not mere labels. Thirty-eight Yorùbá indigenous names were classified into eight different groups, using factors like relationship to royalty, acknowledging the greatness of Islamic, Christian or traditional deities, circumstances or events at birth, family vocation or profession, infantile mortality, importance of children to the family, 'natural' names and admonitions. From the analysis carried out, Yorùbá indigenous names were shown to perform speech acts like 'assertive', 'directive', 'commissive', 'expressive' and 'declaration', together with varying sub-acts. This shows them to be utterances that derive their meanings from the cultural beliefs of the Yorùbá people, rather than being mere labels. Thus their understanding will help in understanding aspects of the cultural practices of the Yorùbá people and, consequently, the people themselves.
\end{abstract}

\section{Keywords}

speech act, indigenous, anthroponyms, ethno- pragmatic, speech community.

\section{ANÁLISIS DEL DISCURSO DE UNA SELECCIÓN DE ANTROPÓNIMOS DEL YORUBA}

\section{Resumen}

Este trabajo utiliza un enfoque basado en el análisis de los actos de habla en nombres indígenas del yoruba para resaltar que no se trata de meras etiquetas. Se han clasificado treinta y ocho nombres indígenas del yoruba en ocho grupos diferentes, utilizando factores como la relación con la realeza, reconocimiento de la grandeza de lo islámico, lo cristiano o las deidades tradicionales, las circunstancias o eventos en el 
nacimiento, la vocación de la familia o la profesión, la mortalidad infantil, la importancia de los niños en la familia, los nombres "naturales" y las admoniciones. A partir del análisis realizado, se ha demostrado como los nombres indígenas del Yoruba ejecutaban actos de habla de tipo asertivo, directivo, comisivo, expresivo y declarativo, junto con diferentes sub-actos. Esto muestra que son expresiones que derivan su significado de las creencias culturales del pueblo yoruba, en lugar de ser meras etiquetas. Por lo tanto su comprensión ayudará a entender los aspectos de las prácticas culturales del pueblo yoruba y, en consecuencia, la gente misma.

\section{Palabras clave}

acto de habla, indígena, antropónimos, etnopragmática, comunidad de habla

\section{Introduction}

This paper uses a speech act approach to analyze some selected Yorùbá indigenous names to complement existing studies on African anthroponyms, which look at indigenous African names from historical, socio-cultural and syntactic perspectives. The goal of the paper is therefore to harness historical, socio-cultural and syntactic perspectives on Yorùbá personal names in carrying out a speech act study of such names. This will show, among other things that it is not only for translators and translatologists that syntactic values and sociolinguistic import of names present rich opportunities of study, as Bariki (2009) points out, but they are also of value in a speech act analysis of Yorùbá indigenous personal names.

As rightly observed by Bariki, "in many African languages, personal names have a strong historical, socio-cultural and ethnopragmatic bearing that go beyond mere identity or referentiality" (Bariki 2009: 46). In fact, Yorùbá indigenous names are not arbitrary, as they are loaded with meanings and perform diverse speech acts which include appreciating a deity, expressing a wish, requesting a favour, asserting a position or viewpoint, etc. These functions can be very well captured and expressed through a speech act analysis of such names. Not only this, Yorùbá indigenous personal names are normally in sentences that vary in length and complexity, properties which make them appropriate data for a speech act study. 
The data for this study are an assortment of randomly selected thirty-eight Yorùbá indigenous names which we classify into different groups that explain why the names were chosen in the first place. The classification cuts across those done by Agyekum (2006), as cited in Bariki (2009), for Akan personal names, Oseni (2004) for Muslim names in Nigeria and Babalọla \& Alaba (2003) for Yorùbá personal names. While these classifications overlap in some instances, they have some peculiarities which are informed by the research focus of the respective authors. The names that will feature in this study are Yoruba indigenous names. They exclude Muslim or Christian names, as well as cognomens (oríki- orúkọ). We regard as indigenous or traditional names those names that are usually referred to as middle names, which are given, together with other names, at a child's naming ceremony. In other words, the data for this study exclude such cognomens as Àjàgbé, Àdigún, Àbíkẹ, etc, but include such names as Ọlọrunfẹmi, Ògúnbùnmi, Èyítáyọ̀, Oládiméjì, Adégbìjà etc. Because our data exclude cognomens and names of foreign origin, we have decided to refer to them as traditional or indigenous names rather than personal names, which will include any name that a person is called and recognized by.

The thirty-eight names in this work and their meanings are obtained largely from our intuition as native speakers of Yorùbá language and from Babalọla \& Alaba (2003). The format we have adopted is to classify the names into eight groups that give the backgrounds to the choice of the names. Since Yorùbá indigenous names are usually sentences that are nominalized, in our analysis, the nominalized forms are presented first, followed by the sentences from which they are derived. The sentence-names are glossed, followed by the direct and indirect speech acts that they express, respectively.

\section{Objective of the study}

The objective of this study is to show the communicative import of Yorùbá indigenous names through a speech act analysis. This will further show how deeply rooted in culture Yorùbá indigenous names are and reiterate the close relationship between language and culture. It will also buttress the fact that Yorùbá indigenous names are not just labels, titles or appendages, but different forms of speech acts that situate their 
bearers properly within their cultural milieu, and express their essence holistically as rational beings within their cultural and traditional practices. The study will show that Yorùbá indigenous names constitute a distinct speech repertoire within the Yorùbá communication system and can shed light on the Yorùbá people's belief systems and cultural practices, as a step towards understanding the people themselves.

\section{Names and naming practices in the Yorùbá Speech Community}

As pointed out by Coggin (2010), naming traditions in Africa is region based and most names refer to the details surrounding a child's birth, such as the season, day of the week, number of family members, or the emotional state of the family during birth. Yorùbá indigenous names in particular, are deeply rooted in the cultural practices and belief systems of the Yorùbá people. They express diverse meanings which reveal a lot about the historical, social, psychological and cultural backgrounds of the Yorùbá people. In effect, a Yorùbá person's indigenous name can shed some light on the bearer's family backgrounds, e.g. family occupation, religion, emotional state (particularly regarding child-bearing) and the importance of children to the family, etc. It can, therefore, be asserted that a Yorùbá indigenous name is an embodiment of a lot of stories about the bearer's family. Thus, in the words of Bariki (2009), African names (indeed Yorùbá names) have a strikingly semantic and semiotic load that has communicative functions despite their monoreferential status.

\section{Classification of Yorùbá names}

Oseni (2004) notes that it is customary among Nigerians to classify names into two: foreign and indigenous. He, however, prefers to classify Nigerian names into three, the first being based on the meaning of such names, the second on hero-worship and the third on the circumstances surrounding the birth or life of the child. On the meaning of names, Oseni (2004) observes that many people all over the world give certain names to their children because of the special meaning that such names have. However, since our 
position is that all Yorùbá names are of great semantic import, we will not use meaning as an independent index for classifying Yorùbá indigenous names. Indeed, all our classifications are possible because the names have semantic interpretation.

The second index used by Oseni is hero-worshiping. By this, he means names that are given after a particular hero who "might have immortalized her/his name in the opinion of the people by their bravery, morality, righteousness, courage, kindness, sincerity, chastity and what have you" (Oseni 2004: 3). Unfortunately, Oseni's examples of such names are all foreign names. Yorùbá names that may fall under this class of names are those given in appreciation or anticipation of some good turns from Islamic, Christian or traditional deities. They are not names given to hero-worship the original bearers. No Yorùbá would, for instance, name her/his child Șàngo, Ọya or Ò̀sun, neither would a Yorùbá name her/his child Ògèdènggbé, Àfọnjá, Gbọ̀ńkà etc, to hero-worship those that first bore such names. To do so may be considered an affront to the initial bearers of the names, as it is evidenced by the fact that children named after their grandparents or parents are rarely called by such names in deference to those grandparents and parents. Instead the children are addressed as Olóókọ-bàbá (Father's namesake) or Olóóko-ìyá (Mother's namesake) or 'Junior'. Our observation is that names that fall under Oseni's hero-worship are generally foreign names of Islamic or Christian background, and are largely names specific to prophets, their companions or angels. The conclusion that can be drawn from this observation is that no Yorùbá name would fit into Oseni's hero-worship class.

As observed by Oseni (2004), most names are determined by circumstances surrounding the birth (or the entire lives) of the people who bear them. This must have informed his third class of names- those relating to circumstances surrounding the life of a person. He then gives a list of such circumstances as historical, social, economic, geographical, professional, traditional or "derogation of certain traits (real or imaginary) found in a person so named" (Oseni 2004: 5), making a total of seven circumstantial names. Our view on Oseni's third class of names is that instead of bringing all the seven sub-classes of "circumstances surrounding the life of a person" under one umbrella, each sub-class can be treated as a bona-fide class of names, including "circumstances at birth" itself, as we shall do in our own classification. 
On the basis of the patterns which are discernible from a semantic analysis of Yorùbá names, Babalọla \& Alaba (2003) classify them into sixteen, eight of which are praise names, which fall outside the purview of this study, leaving eight others, which are: (i) chieftaincy title that persists as a personal name; (ii) name reflecting an event anticipated by the family at the time of the child's birth; (iii) name that reflects the child's inevitable participation in a cult or the child's coincidental arrival during a festival or some other special event; (iv) name that reflects the specific spatial location of the child's birth; (v) name reflecting an important family tradition, circumstances, possession or mood that the child found, or did not find, on arriving in the home; (vi) name that reflects parents' or grand-parents' estimation of the child's excellence and or the child's role in the family; (vii) name that constitutes a declaration made or comment passed by the father or grandfather or other elder on the child's birth; (viii) name reflecting the child's presumed comment on the family, uttered soon after the child's arrival into that family. Our own classification over-laps with and is distinct from Babalọla \& Alaba's in some specific areas, as we shall show shortly.

Adopting a socio-cultural interpretation of names, Agyekum (2006), as cited in Bariki (2009), classifies Akan names into the following: (i) Day names; (ii) Family names; (iii) Circumstantial names (iv) Theophorous names; (v) Flora and Fauna; (vi) Weird and reincarnate names; (vii) Achievement names; stool (i.e. royal) names, religion, occupational); (viii) Insinuating and Proverbial names; (ix) Bodily structure and (x) Kinship, among others. As in the case of the other classifications, our classification incorporates aspects of Agyekum's typologies, while it excludes some. For example, our classification does not have day names, as such names do not fall within our corpus of data. Agyekum's achievement names are given separate classifications in our own study. For instance, we have names relating to royalty, reverence for deities and occupational names. Agyekum's insinuating and proverbial names are classified under admonition, while names under his bodily structure fall in the class of names generally referred to as inagije' (pen names) in Yorùbá and, therefore, do not form part of the data for this study. The same applies to names under flora and fauna (which will be regarded as pen names in Yorùbá) and kinship names, which fall under Babalọla \& Alaba's (2003) praise names. Agyekum's weird and reincarnate names form part of the names in our own natural and infantile mortality classes. 
In summary, our classification of Yorùbá indigenous personal names are eight and are based on factors such as Royalty, Deities, Circumstances or events at birth, Vocation or Profession, Infantile mortality, Importance of children in the family, "Natural" names, and names that are admonitions. All these names have cultural, social, historical and psychological bases in the Yorùbá speech community as a whole and can be captured in a speech act analysis.

\section{Theoretical background: the speech act theory}

Speech acts are "the actions speakers perform in uttering sentences including informing, promising, requesting, questioning, commanding, warning, preaching, congratulating, laying bets, swearing and exclaiming" (McGregor 2009: 142). Since Austin's (1962) pioneering work on speech acts, quite a lot has been done on speech act analysis. In its original formulation, Austin (1962) draws a distinction between constative and performative utterances, the former referring to statements whose function is to describe some event, process or state of affairs and has the property of being either true or false (Lyons 1977). Performative utterances on the other hand, have no truth-value, as "they are used to do something rather than to say that something is or is not the case" (Lyons 1977: 726). Thus, Austin draws a distinction between saying something (constative) and doing something (performative) by means of language and by so doing, he emphasizes the importance of relating the functions of language to the social contexts in which language operates (Lyons 1977). Yorùbá indigenous names, generally fall under Austin's performatives, as they have semantic content that relate them to the socio-cultural, traditional and historical contexts that give rise to them, rather than function as constative utterances.

Austin also distinguishes between primary and explicit performatives, the former containing performative verbs like promise, warn, direct, etc. while the latter do not. Yorùbá indigenous names generally contain performative verbs and can therefore be classified as explicit performative utterances. He also made a distinction among locutionary, illocutionary and perlocutionary acts (Lyons 1977: 730). A locutionary act 
refers to the act of saying. It is the production of a meaningful utterance. Yorùbá indigenous names, as we earlier said, are meaningful sentences that can be semantically analyzed.

On the other hand, an illocutionary act is an act performed in saying something. Here, saying amounts to doing. Thus, one can make a statement, a promise, issue a threat or assert a proposition etc. A perlocutionary act is the effect produced by what is said on the listener/hearer. It is the consequential effect of an utterance on the listener/hearer. Thus, we agree with Lyons (1977) that the meaning of an utterance involves, of necessity, the sender's communicative intention and that understanding an utterance necessarily involves the receiver's recognition of the sender's communicative intention. To the extent that the Yorùbá believe that the name given to a child has divinatory effects on her/his life, we can say that Yorùbá indigenous names generate perlocutionary effects in their bearers. Also, as Lyons points out, "in all languages, sentences are systematically associated with the illocutionary acts that may be performed in uttering them" (Lyons 1977: 733). Yorùbá indigenous names are made up of different sentences which predetermine their illocutionary act potentials.

According to Austin, for an illocutionary act to generate the desired force, it must abide by what he refers to as felicity conditions, which include the existence of an accepted conventional procedure having a certain conventional effect, the procedure to include the uttering of certain words by certain persons on certain circumstances (Jaworski \& Coupland (1999), as cited in Omọlọsộ (2006)). Felicity condition thus requires that an utterance must be produced by the appropriate person, on an appropriate occasion and in an appropriate context, if it is to have the desired communicative effect. Thus, a teacher, while teaching in the class, cannot, for example, legitimately join a male student and a female student in his class in marriage by saying, "I hereby pronounce you husband and wife". The utterance will not generate the effect of making the affected students truly husband and wife. For Yorùbá indigenous names to qualify as illocutionary acts that will generate the desired force, all the conditions necessary to make naming conform with the naming practices in Yorùbá culture must be upheld.

Searle (1969), as cited in Leech \& Thomas (1990), agrees with Austin that meaning amounts to a kind of doing, but proposes what he calls essential conditions or rules that 
should be followed for a given speech act to be effectively performed. These are propositional content condition or rules which specify the kind of meaning that the propositional part of an utterance expresses; preparatory conditions which are prerequisite to the performance of the speech act; sincerity conditions that specify the conditions that should obtain for the speech act to be sincerely performed; and essential conditions which specify what the speech act is with reference to convention.

The naming practices in the Yorùbá speech community fulfill all of the four essential conditions highlighted by Searle. For instance, the name that is given to a child must be propositionally meaningful, thus fulfilling Searle's propositional content condition. Secondly, the norms that govern naming practices within the Yorùbá speech community constitute the preparatory conditions for giving a child a name. Such conditions must include the birth of a child and the fact that the child survives till the date traditionally set aside for naming a new-born baby. Parts of the sincerity conditions for naming a child are that there is a child to be named, the naming is done by a person or persons designated conventionally to do so, and the members of the family of the baby to be named, particularly the baby's parents (in normal circumstances) are present etc. Essential condition is fulfilled once the name given to the child is meaningful and can be associated with specific aspects of the Yorùbá people's cultural practices and beliefs.

One aspect of Austin's speech act theory that has been the focus of diverse comments is his classification of speech acts, which, according to Lyons (1977), raises the question of whether there is a limit to the number of illocutionary acts that should be recognized in a semantic analysis of human language. This question is pertinent because of the fact that languages, particularly the Yorùbá language, have a rather limitless number of performative verbs. Do we assign a speech act to every performative verb or can we combine the performative verbs to form a relatively small number? Searle (1969), cited in Leech \& Thomas (1990) appears to have answered this question by classifying all possible speech acts in human languages into five. His classification, which we shall adopt for our analysis in this study, is as follows:

(a) Assertives, which commit the speaker to the truth of some proposition. Such include, for example, stating, claiming, reporting, informing, noticing etc. 
(b) Directives, which refer to an attempt to bring about some effect through the action of the hearer, e.g. ordering, requesting, demanding, begging, appealing, etc.

(c) Commissives, which commit the speaker to some future action like promising, offering, swearing to do something, vowing, pledging.

(d) Expressives: These refer to the expressions of some psychological state like thanking, congratulating, apologizing, admonishing, eulogizing, etc.

(e) Declarations: They refer to speech acts whose successful performance brings about a correspondence between the propositional content and reality, like, for example, naming a ship, or a child, sentencing, resigning, condemning etc.

As we shall point out in our analysis later, all the Yorùbá indigenous names that constitute our corpus of data can be captured under Searle's five classes of speech acts. This shows, as Ọdẹbùnmi (2006), cited in Friday-Ọtun (2010) remarks, that Searle's (1969) classification has relevance in cross-cultural pragmatics.

An area of the speech act theory that is very important to the speech act analysis of Yorùbá indigenous names is the concept of implicature. Implicature refers to what is implied but not entailed (Grice 1975). Implicature plays a crucial role in assigning Yorùbá indigenous names to specific speech acts. For example, Olúwadámiláre (God has vindicated me) which, using Searle's classification, is Assertive, implies that the arrival of the child relieves the parents of some earlier burden, or malicious insinuation. The same can be said of Ògúnrẹmílẹkún (the god of iron has comforted me), which implies that prior to the arrival of the new child, the family whose members are worshippers of ògún (god of iron) or hunters by profession, were in one form of grief or the other. The relevant implicature here is conversational implicature, a situation where the speaker means more than what she/he has expressed. Context thus plays a major role in conversational implicature, unlike in conventional implicature, where what is meant is implied by the meaning of what is expressed. However, meaning is very crucial in both conventional and conversational implicatures, because, as Lyons (1977) states, illocutionary acts are governed and determined by a general condition of meaningfulness. This implies that an utterance cannot be assigned to any speech act unless it satisfies the general condition of meaningfulness. Applied to Yorùbá indigenous names, a Yorùbá indigenous name must 
first of all have propositional and semantic contents to qualify for classification into any specific speech act.

The issue of the meaningfulness of an utterance brings into focus the relevance of context in the determination of utterance meaning and the assignment of utterances into specific speech acts. According to Leckie-Tarry (1995), all meaning is determined by contextualization. Mey describes context as all the factors that play a role in producing and understanding utterances. It is dynamic in nature, as it is "in steady development, prompted by the continuous interaction of the people engaged in language use" (Mey 2001: 14). According to Mey (2001), an utterance makes no sense until it is placed in its human context - the language user's world - which is the speaker's linguistic, social, cultural and general life contexts. In the view of Bilmes (1986), cited in Mey (2001), "the meaning of an utterance is determined, to a great extent, by how it responds and how it is responded to, by its place in an interactional sequence, which is a context of use" Bilmes (2001: 30). Context is user-oriented, so, it is dynamic, and it differs from user to user, from user group to user group and therefore, from language to language. Context is, therefore, what gives utterances their speech acts. Yorùbá indigenous names are meaningful only when related to the socio-cultural and traditional contexts that give rise to them in the first place, as it is within these socio-cultural and traditional contexts that they constitute different speech acts.

Following Mey's (2001) observation that since language is a product of a social context, its use is governed by society rather than by the individual speakers, we can infer that all speech acts are "ritual" acts, particularly since context determines what one can say and what one cannot say. This then brings us to what Lyons (1977) refers to as the universality of particular speech acts. According to him, certain basic illocutionary acts like making statements, asking questions, issuing commands or making requests are universal, in the sense that they are acts "that all human societies perform, though there are certain speech acts that would seem to be dependent upon legal or moral concepts institutionalized in particular societies" (Lyons (1977: 737). Among such acts would be acts of swearing on oath in a court of law, Austin's (1962) naming a ship, giving a child a name in an appropriate social context, acts which, according to Lyons (1977), are conventional and culture specific. Based on the foregoing observations, we propose a basic typology of 
speech acts. Our proposal incorporates what Lyons (1977) refers to as universal acts and acts that are "dependent upon legal or moral concepts institutionalized in particular societies" (Lyons 1977: 73).

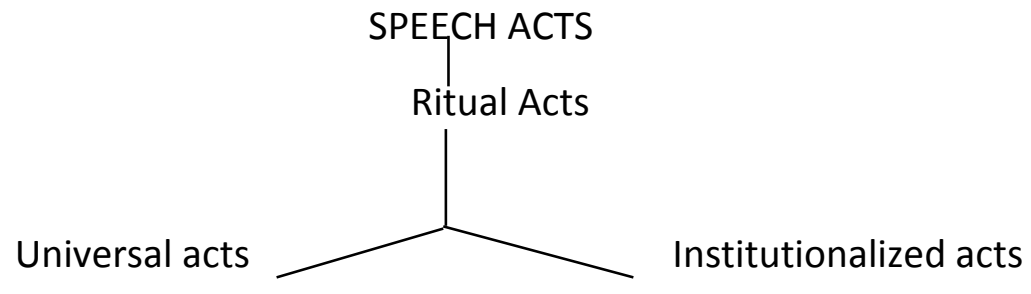

Figure 1. A model of basic speech act typologies

Our proposal is that all speech acts are ritual in nature, as all forms of language use are constrained by contextual variables which condition the speaker to conduct her/his language use in certain ways. That is, no matter the domain of use, there are general universal constraints placed on language use, the observance of which qualifies one as being communicatively competent in that language. Ritual acts could be universal or institutional. Universal acts would cover language use in all contexts apart from institutionalized domains. Thus, language use in all informal contexts like the home, market, street, etc. will come under universal acts. Speech acts performed in these domains will contain sub-acts which will further distinguish speech acts performed in the family from those performed in the market place or street. On the other hand, institutionalized acts will cover all forms of language use in such formal contexts like the court-room, marriage registry, government/official functions, mosque/church, naming ceremonies, ordination ceremonies, commissioning ceremonies, etc. Ritual acts can be regarded as abstract acts, or tokens, just like entries in a general purpose dictionary, which are assigned "abstract" meanings that often change in real contexts. Thus when a ritual act is confronted with specific contexts, it may become an institutionalized act or a universal act.

In the following section, we shall present and analyze our data, which, following the model presented above, come under institutionalized speech acts. Searle's five classes of speech acts will be used for our analysis. 


\section{Presentation and analysis of data}

The data for this study are made up of thirty-eight randomly selected Yorùbá indigenous names classified into eight groups, viz.: Royalty, Deities, Circumstances or events at birth, Family's vocation or profession, Infantile mortality, Importance of children in the family, "Natural" names, and Admonitions. Our analysis indicates the direct and indirect speech acts that the names belong to, relying on the structure and meaning of the sentence-names. Direct speech acts are those overtly suggested by the structures of the sentence-names, e.g. declarative, imperative or interrogative (Allan 1986). Indirect speech acts are inferred from a combination of the structure of the sentence - names and the knowledge of the socio-cultural, traditional and historical contexts from which the names originate. In the data that follow, the nominalized forms of the names are first presented, followed by the sentences from which the nominalized forms are derived. The sentencenames are then glossed, followed by their direct and indirect speech acts. The sub-acts performed by the speech acts are given in brackets after the speech acts.

Yorùbá indigenous names and their direct and indirect speech acts

\begin{tabular}{|c|c|c|c|c|c|}
\hline \multirow{2}{*}{$\begin{array}{l}\text { A. } \\
\text { S/N }\end{array}$} & \multicolumn{3}{|c|}{ Royalty-related names } & Direct & Indirect \\
\hline & $\begin{array}{l}\text { Indigenous } \\
\text { Name }\end{array}$ & $\begin{array}{l}\text { Sentence from which } \\
\text { name is derived }\end{array}$ & $\begin{array}{l}\text { English translation of } \\
\text { sentence-name }\end{array}$ & \multicolumn{2}{|c|}{ Speech act of sentence-name } \\
\hline 1. & Adéyẹmí & Adé yẹ mí. & Crown fits me & Declarative & $\begin{array}{l}\text { Assertive } \\
\text { (Claiming) }\end{array}$ \\
\hline 2. & Adéyímiká & Adé yí mi ká & I am surrounded by crowns & Declarative & $\begin{array}{l}\text { Assertive } \\
\text { (Reporting) }\end{array}$ \\
\hline 3. & Jókòótadé & Jókòó ti adé & $\begin{array}{l}\text { Sit with the crown/Stay with } \\
\text { the crown }\end{array}$ & Imperative & $\begin{array}{l}\text { Directive/Re- } \\
\text { questive } \\
\text { (Begging, } \\
\text { Pleading) }\end{array}$ \\
\hline 4. & Gbádégẹsin & Gbé adé gun ẹsin. & Put crown on horse-back & Imperative & $\begin{array}{l}\text { Directive/Reque } \\
\text { stive } \\
\text { (Requesting) }\end{array}$ \\
\hline 5. & Oyèbámijí & Oyè bá mi jí & $\begin{array}{l}\text { a) Chieftaincy/Royalty wakes } \\
\text { up with me. } \\
\text { b) I wake up with } \\
\text { royalty/chieftaincy. }\end{array}$ & Declarative & $\begin{array}{l}\text { Assertive } \\
\text { (Reporting) }\end{array}$ \\
\hline 6. & $\begin{array}{l}\text { (Ọmọ)gbádébọ } \\
\text { wálé }\end{array}$ & $\begin{array}{l}\text { (Ọmọ) gbé adé bọ̀ wá } \\
\text { ilé. }\end{array}$ & $\begin{array}{l}\text { (Child) brings the crown } \\
\text { back home. }\end{array}$ & Declarative & $\begin{array}{l}\text { Assertive } \\
\text { (Stating, } \\
\text { Reporting) }\end{array}$ \\
\hline 7. & Jẹ́jẹ́loyẹ̀ & Jẹjjẹ ni oyè. & $\begin{array}{l}\text { Royalty is filled with } \\
\text { dignity/patience. }\end{array}$ & Declarative & $\begin{array}{l}\text { Assertive } \\
\text { (Stating) }\end{array}$ \\
\hline
\end{tabular}




\begin{tabular}{|c|c|c|c|c|c|}
\hline \multirow{2}{*}{$\begin{array}{l}\text { B. } \\
S / N\end{array}$} & \multicolumn{3}{|c|}{ Deity-related names } & Direct & Indirect \\
\hline & $\begin{array}{l}\text { Indigenous } \\
\text { Name }\end{array}$ & $\begin{array}{l}\text { Sentence from which } \\
\text { name is derived }\end{array}$ & $\begin{array}{l}\text { English translation of sentence- } \\
\text { name }\end{array}$ & \multicolumn{2}{|c|}{$\begin{array}{l}\text { Speech act of sentence- } \\
\text { name }\end{array}$} \\
\hline 8. & $\begin{array}{l}\text { (Mo)fọ́lọ́unșọ́/ } \\
\text { fọ́lộrunșọ́ }\end{array}$ & $\begin{array}{l}\text { Mo fún Olọ́run (ní } \\
\text { èyi) sọ́. }\end{array}$ & I give (this) to God to watch over. & Declarative & $\begin{array}{l}\text { Declaration } \\
\text { (offering) }\end{array}$ \\
\hline 9. & Ògúnwándé & Ògún wá mi dé. & God of iron has located me & Declarative & $\begin{array}{l}\text { Assertive } \\
\text { (Reporting) }\end{array}$ \\
\hline 10. & Oșúnbùnmi & Oșun bùn mi. & $\begin{array}{l}\text { Goddess of River Osun gives (this) } \\
\text { to me. }\end{array}$ & Declarative & $\begin{array}{l}\text { Assertive } \\
\text { (Reporting) }\end{array}$ \\
\hline 11. & Ifáwọlé & Ifá wọ ilé. & $\begin{array}{l}\text { God of divination has entered the } \\
\text { house. }\end{array}$ & Declarative & $\begin{array}{l}\text { Assertive } \\
\text { (Reporting) }\end{array}$ \\
\hline 12. & Oyatóògùn & Oya tó oògùn. & $\begin{array}{l}\text { a) The goddess of River Niger is } \\
\text { enough as medication. }\end{array}$ & Declarative & $\begin{array}{l}\text { Assertive } \\
\text { (Claiming) }\end{array}$ \\
\hline 13. & Olúwarẹ̀mílẹkún & Olúwa rẹ̀ mí ní ẹkún. & $\begin{array}{l}\text { a) God has consoled me. } \\
\text { b) God has stopped my crying. } \\
\text { c) God has wiped my tears for } \\
\text { me. }\end{array}$ & Declarative & $\begin{array}{l}\text { Assertive } \\
\text { (Reporting) }\end{array}$ \\
\hline 14. & Àánúolúwapọ & Àánú Olúwa pọ̀. & $\begin{array}{l}\text { a) God's mercy is plenty. } \\
\text { a) God is full of mercy. }\end{array}$ & Declarative & $\begin{array}{l}\text { Assertive } \\
\text { (Stating) }\end{array}$ \\
\hline 15. & Modúpẹolúwa & Mo dúpẹ, Olúwa. & a) I thank you, God. & Declarative & $\begin{array}{l}\text { Expressive } \\
\text { (Thanking, } \\
\text { Eulogising) }\end{array}$ \\
\hline
\end{tabular}

\begin{tabular}{|c|c|c|c|c|c|}
\hline \multirow{2}{*}{$\begin{array}{l}\text { C. } \\
\text { S/N }\end{array}$} & \multicolumn{3}{|c|}{ Names related to circumstances/events at birth } & Direct & Indirect \\
\hline & $\begin{array}{l}\text { Indigenous } \\
\text { Name }\end{array}$ & $\begin{array}{l}\text { Sentence from which } \\
\text { name is derived }\end{array}$ & $\begin{array}{l}\text { English translation of } \\
\text { sentence-name }\end{array}$ & \multicolumn{2}{|c|}{ Speech act of sentence-name } \\
\hline 16. & Morẹenikéjì & Mo rí ẹni șe ìkejì. & I have a supporter. & Declarative & $\begin{array}{l}\text { Assertive } \\
\text { (Claiming, } \\
\text { Stating, } \\
\text { Reporting) }\end{array}$ \\
\hline 17. & Ọmọbọ́láńlé & Ọmọ bá ọlá ní ilé. & Child meets wealth at home. & Declarative & $\begin{array}{l}\text { Assertive } \\
\text { (Claiming) }\end{array}$ \\
\hline 18. & $\begin{array}{l}\text { Májẹẹéyàógbé } \\
\text { /Májìyàgbé }\end{array}$ & $\begin{array}{l}\text { a) Má jẹ̀ kí ìyà mi ó } \\
\text { gbé. } \\
\text { b) Má jẹ ìyà gbé. }\end{array}$ & $\begin{array}{l}\text { a) Don't let (my) suffering be } \\
\text { for nothing/in vain. } \\
\text { b) Don't suffer in vain. }\end{array}$ & Imperative & $\begin{array}{l}\text { Directive } \\
\text { (Pleading) }\end{array}$ \\
\hline 19. & Ẹkúndayọ & Ẹkún (mi) di ayọ. & $\begin{array}{l}\text { (My) weeping/crying has } \\
\text { turned to joy. }\end{array}$ & Declarative & $\begin{array}{l}\text { Assertive } \\
\text { (Reporting, } \\
\text { Stating) }\end{array}$ \\
\hline 20. & İyábọ̀wálé & Ìyá padà bọ̀ wá ilé. & Mother has come back home. & Declarative & $\begin{array}{l}\text { Assertive } \\
\text { (Reporting) }\end{array}$ \\
\hline
\end{tabular}

\begin{tabular}{|c|l|l|l|l|l|}
\hline D. & \multicolumn{2}{|l|}{ Vocation/Profession-related names } & \multicolumn{2}{l|}{ Direct } & Indirect \\
\hline S/N & $\begin{array}{l}\text { Indigenous } \\
\text { Name }\end{array}$ & $\begin{array}{l}\text { Sentence from which } \\
\text { name is derived }\end{array}$ & $\begin{array}{l}\text { English translation of } \\
\text { sentence-name }\end{array}$ & \multicolumn{2}{|l|}{ Speech act of sentence-name } \\
\hline 21. & Ọdẹ́bùnmi & Ọdẹ bùn mi. & Hunting/Hunter gives me. & Declarative & $\begin{array}{l}\text { Assertive } \\
\text { (Stating, } \\
\text { Reporting) }\end{array}$ \\
\hline 22. & Àyàntúndé & Àyàn tún dé. & $\begin{array}{l}\text { The drummer has come back } \\
\text { again. } \\
\text { Another drummer has come. }\end{array}$ & Declarative & $\begin{array}{l}\text { Assertive } \\
\text { (Reporting, } \\
\text { Stating) }\end{array}$ \\
\hline
\end{tabular}


Dialectologia 15 (2015), 117-135.

ISSN: 2013-2247

\begin{tabular}{|c|l|l|l|l|l|}
\hline 23. & Odẹ́wùmí & Odẹ wù mí. & Hunting appeals to me & Declarative & $\begin{array}{l}\text { Assertive } \\
\text { (Stating) }\end{array}$ \\
\hline 24. & Kéwúgbèmí & Kéwú gbè mí. & $\begin{array}{l}\text { The Qur'an suits me. } \\
\text { Learning of the Qur'an suits } \\
\text { me. }\end{array}$ & $\begin{array}{l}\text { Declarative } \\
\text { (Reportive }\end{array}$ \\
\hline
\end{tabular}

\begin{tabular}{|c|l|l|l|l|l|}
\hline E. & \multicolumn{2}{|l|}{ Infantile Mortality-related names } & \multicolumn{2}{l|}{ Direct } & \multicolumn{2}{l|}{ Indirect } \\
\hline S/N & $\begin{array}{l}\text { Indigenous } \\
\text { Name }\end{array}$ & $\begin{array}{l}\text { Sentence from which } \\
\text { name is derived }\end{array}$ & $\begin{array}{l}\text { English translation of } \\
\text { sentence-name }\end{array}$ & \multicolumn{2}{l|}{ Speech act of sentence-name } \\
\hline 25. & Dúróoríkẹé & Dúró kí o rí ikẹ́. & Stay alive and be pampered. & Imperative & $\begin{array}{l}\text { Commissive } \\
\text { (promising) }\end{array}$ \\
\hline 26. & Dúrójayé & Dúró kí o jẹ ayé. & $\begin{array}{l}\text { Stay alive and enjoy life/the } \\
\text { world. }\end{array}$ & Imperative & $\begin{array}{l}\text { Commisive } \\
\text { (promising) }\end{array}$ \\
\hline 27. & Níhìnínlọláwà & Ní ibí yî́ ni ọlá wà. & $\begin{array}{l}\text { It is here (in the world) that } \\
\text { wealth is. }\end{array}$ & Declarative & $\begin{array}{l}\text { Assertive } \\
\text { (Requesting/ } \\
\text { Pleading) }\end{array}$ \\
\hline 28. & Kòsọ́kọ́ & Kò sí ọkó. & There is no hoe. & Declarative & $\begin{array}{l}\text { Assertive } \\
\text { (Requesting, } \\
\text { Pleading) }\end{array}$ \\
\hline 29. & İgbẹ́kọ̀yí & İgbẹ́ kọ èyí & $\begin{array}{l}\text { The bush has rejected this } \\
\text { one. }\end{array}$ & Declarative & $\begin{array}{l}\text { Assertive } \\
\text { (Reporting, } \\
\text { Stating) }\end{array}$ \\
\hline
\end{tabular}

\begin{tabular}{|c|l|l|l|l|l|}
\hline F. & \multicolumn{2}{|l|}{ Names indicating importance of children } & \multicolumn{2}{l|}{ Direct } & Indirect \\
\hline S/N & $\begin{array}{l}\text { Indigenous } \\
\text { Name }\end{array}$ & $\begin{array}{l}\text { Sentence from which } \\
\text { name is derived }\end{array}$ & $\begin{array}{l}\text { English translation of } \\
\text { sentence-name }\end{array}$ & \multicolumn{2}{|l|}{ Speech act of sentence-name } \\
\hline 30. & Omọlọsọ́ & Ọmọ ni ọsọ́. & Child is wealth/treasure & Declarative & $\begin{array}{l}\text { Assertive } \\
\text { (Claiming) }\end{array}$ \\
\hline 31. & Omọtọ́ṣọọ & Ọmọ tó ní ọṣọ́ & $\begin{array}{l}\text { Child is valuable enough as } \\
\text { treasure/wealth. }\end{array}$ & Declarative & $\begin{array}{l}\text { Assertive } \\
\text { (Claiming) }\end{array}$ \\
\hline 32. & Omọ́yẹlé & Ọmọ yẹ ilé & Child fits home. & Declarative & $\begin{array}{l}\text { Assertive } \\
\text { (Stating) }\end{array}$ \\
\hline 33. & Omọ́dùnúnní & Ọmọ dún-ún ní. & Child is good to have. & Declarative & $\begin{array}{l}\text { Assertive } \\
\text { (Stating) }\end{array}$ \\
\hline
\end{tabular}

\begin{tabular}{|c|l|l|l|l|l|}
\hline G. & \multicolumn{2}{|l|}{ "Natural" names } & \multicolumn{2}{l|}{ Direct } & Indirect \\
\hline S/N & $\begin{array}{l}\text { Indigenous } \\
\text { Name }\end{array}$ & $\begin{array}{l}\text { Sentence from which } \\
\text { name is derived }\end{array}$ & $\begin{array}{l}\text { English translation of } \\
\text { sentence-name }\end{array}$ & \multicolumn{2}{|l|}{ Speech act of sentence-name } \\
\hline 34. & Omọtáyéwò & Ọmọ tọ ayé wò. & $\begin{array}{l}\text { The child tastes/samples the } \\
\text { world. }\end{array}$ & Declarative & $\begin{array}{l}\text { Assertive } \\
\text { (Reporting) }\end{array}$ \\
\hline 35. & Omọ́kẹyìndé & Ọmọ kẹyìn dé & Child comes last. & Declarative & $\begin{array}{l}\text { Assertive } \\
\text { (Reporting) }\end{array}$ \\
\hline
\end{tabular}




\begin{tabular}{|c|c|c|c|c|c|}
\hline \multirow{2}{*}{$\begin{array}{l}\text { H. } \\
\text { S/N }\end{array}$} & \multicolumn{3}{|l|}{ Admonitions } & Direct & Indirect \\
\hline & $\begin{array}{l}\text { Indigenous } \\
\text { Name }\end{array}$ & $\begin{array}{l}\text { Sentence from which } \\
\text { name is derived }\end{array}$ & $\begin{array}{l}\text { English translation of } \\
\text { sentence-name }\end{array}$ & \multicolumn{2}{|c|}{ Speech act of sentence-name } \\
\hline 36. & İjàòdọlà & İjà kò di ọlà & $\begin{array}{l}\text { Quarreling does not bring } \\
\text { salvation/wealth. }\end{array}$ & Declarative & $\begin{array}{l}\text { Assertive } \\
\text { (Admonishing) }\end{array}$ \\
\hline 37. & Máfikúyọ̀mí & $\begin{array}{l}\text { Má fi ikú (ọkọ/aya } \\
\text { etc) yọ̀ mí. }\end{array}$ & $\begin{array}{l}\text { Don't mock me on account of } \\
\text { (my husband's/wife's etc) } \\
\text { death. }\end{array}$ & Imperative & $\begin{array}{l}\text { Directive } \\
\text { (admonishing) }\end{array}$ \\
\hline 38. & Tanímọla & Ta ni ó mọ ọ̀la? & $\begin{array}{l}\text { Who is it that knows } \\
\text { tomorrow }\end{array}$ & Interrogative & $\begin{array}{l}\text { Requestive } \\
\text { (Warning) }\end{array}$ \\
\hline
\end{tabular}

\section{Observations on data analysis}

Our corpus of data consists of seven royalty-related indigenous names, eight deityrelated names, five names that are based on the circumstances at the child's birth, four family's vocation/profession-related names and five names based on infantile immortality. Others are those based on the importance of children to the family (four), natural circumstances (two) and admonitions, (three), making a total of thirty-eight Yorùbá indigenous names.

It is observed that the direct speech act of most of our selected names is declarative (thirty-one out of thirty-eight names), six are imperative, while only one is interrogative (a rhetorical question). Out of the thirty-one names whose direct speech act is declarative, twenty-seven have Assertive as their indirect speech act, two are Requestives, and one is Expressive, while one is Declaration. Out of the six imperatives, four are Directives/Requestives, while two are Commissives. The only interrogative in the data has Requestive indirect speech act.

We note that each of the indirect speech acts has what Friday-Otun (2010) refers to as sub-acts. For example, the Assertives have sub-acts which are claiming, reporting, stating, or admonishing. The Requestive/ Directive acts are requesting, begging or admonishing. Similarly, the only Expressive act in the corpus of data has thanking or eulogizing as sub-acts, while the Declaration act has a sub-act of offering.

It is also noted that while the direct speech act of each of the sentence-names helps to give an insight into the type of indirect speech act it performs, the meanings of the sentence- names do not. For example, declaratives are generally Assertive, though there 
may be different sub-acts under Assertive, based on contexts. Imperatives have Directives, Requestives or Commissives as indirect speech acts, with varying sub-acts, also as imposed by contexts. Interrogatives have Directive or Requestive speech act, with contextdetermined sub-acts. However, the semantic contents of the sentence-names differ, in the sense that sentence-names with different meanings end up having the same indirect speech acts. For instance, Àyàntúndé (The drummer has come back again or Another drummer has come) and Ọdẹwùmí (Hunting appeals to me) have different meanings, yet they have the same direct speech act (declarative) and the same indirect speech act (Assertive). They also have similar sub-acts (stating or reporting). This, however, does not demean the relevance and importance of utterance meaning to a speech act analysis of utterances, as all utterances must abide by what Searle (1969), cited in Leach and Thomas (1990), calls propositional content conditions or rules that specify the kind of meaning that the propositional part of an utterance expresses. Rather, it goes to show that context plays a major role, in addition to meaning, in assigning utterances to their respective speech acts. In other words, utterance meaning and the context where the utterance features complement each other in a speech act analysis of an utterance.

\section{Summary and conclusion}

This work is a speech act analysis of thirty-eight Yorùbá indigenous names, classified into eight different sub-groups that tell why the Yorùbá speech community likes the names in the first instance. The goal of the study is to shed light on the relationship between the Yorùbá indigenous names and the Yorùbá socio-cultural and traditional beliefs. Earlier works on Yorùbá indigenous names have adopted historical, socio-cultural and syntactic perspectives. The current approach aims at complementing such works with a view to strengthening the fact that Yorùbá indigenous names are not just labels or identification marks, but are rooted in the cultural, social, historical, psychological, spiritual and the general traditional beliefs of the Yorùbá people, and are therefore believed to shape the bearer's journey through life. From our analysis, we have been able to show that Yorùbá indigenous names can be assigned to direct and indirect speech acts. Direct speech acts 
are revealed through the overt functions of the sentence-names, either as declarative, imperative or interrogative. The indirect speech acts are arrived at through an interaction of functions of the sentence names and an understanding of the cultural practices and beliefs of the Yorùbá speech community. Based on these cultural practices and beliefs, and adopting Searle's (1969) five speech act types, we discover that Yorùbá indigenous names perform Assertive, Expressive, Declaration, Directive/Requestive and Commissive acts, which have different sub-acts. Thus, the question as to whether Yorùbá indigenous names are classifiable into direct and indirect speech acts has been answered. We are also able to infer that the classifications relate to the culture and traditions of the Yorùbá people, thereby shedding light on the understanding of the Yorùbá socio-cultural practices, an understanding that we believe can enrich people's understanding of the Yorùbá speech community generally.

\section{References}

Agrekum, K. (2006) The sociolinguistics of Akan personal names, Nordic Journal of African Studies, 15 (2): 206-235.

AlLAN, K. (1986) Linguistic meaning, New York, NY: Routledge and Kegan Paul, plc.

AUstiN, J. (1962) How to do things with words, Cambridge, MA: Havard University Press.

BABALOLA, A. \& O. ALABA (2003) A dictionary of Yoruba personal names, Lagos, Nigeria: West African Book Publishers.

BARIKI, I. (2009) "Translating African names in fiction", Ikala, revista de lenguaje y cultura, 14 (23), 43-61.

BILMES, J. (1986). Discourse and Behaviour, New York and London: Plenum.

CoGGIN, A. (2010) "Name giving across cultures: What's in a name?" <Retrieved from http:// www.divinecaroline.com/22360/45767, 26/2/2013>.

FRIDAY-OTUN, O. (2010) Investigation of children's first-language proficiency at the illocutionary level in selected public primary schools in Ilorin, Kwara State, Nigeria, M. Phil. Dissertation, University of Ibadan.

GRICE, H. P. (1975) "Logic and Conversation", in Peter Cole \& Jerry Morgan (eds.), Syntax and Semantics, Vol. 3, New York: Academic Press, 41-58.

JAWORSKI, A. \& N. Coupland (eds.) (1999) The discourse reader, New York, NY: Routledge. 
Dialectologia 15 (2015), 117-135.

ISSN: 2013-2247

LECKIE-TARRY, H. (1995) Language and context: A functional linguistic theory of register, New York, NY: Pinter.

LeECH, G. \& J. Thomas (1990) “Language, meaning and context: Pragmatics”, in N. E. Collinge (ed.) An encyclopedia of language, London, United Kingdom: Routledge, 173-206.

LYONS, J. (1977) Semantics II, Cambridge, United Kingdom: Cambridge University Press.

McGregor, W. B. (2009) Linguistics: An introduction, London, United Kingdom: Continuum International Publishing Group.

MEY, J. L. (2001)² Pragmatics: An introduction, Australia: Blackwell Publishing.

ỌDẸ́BÙNMI, A. (2006) Meaning in English: An introduction, Ogbomoso: Critical Spheres.

OMoloso, R.K. (2006) A context-structure analysis (CSA) of Yoruba Proverbs in discourse, PhD. Dissertation, Department of Linguistics and Nigerian Languages, University of Ilorin, Nigeria.

OSENI, Z. I. (2004) A guide to Muslim names in Nigeria, Auchi, Nigeria: Darun-Nur.

OYE, A. M. (2012) A sociolinguistic analysis of some selected Yorùbá traditional names, B. A. Dissertation, Al-Hikmah University, Ilorin, Nigeria.

SEARLE, J. R. (1969) "Speech Acts: an introduction to the philosophy of language", in N. E. Collinge (ed.), An Encyclopedia of Language, London and New York: Routledge, 179-184. 